\title{
CONSUMER-BASED BRAND EQUITY OF PRODUCTS AND SERVICES: ASSESSING A MEASUREMENT MODEL WITH COMPETING BRANDS
}

\begin{abstract}
Objective: Identifying which brand in a category conveys more or less value to the consumer raises questions about the composition of brand equity measures and the brands that make up the category. Measures to identify Consumer-Based Brand Equity (CBBE) may include functional assessments of consumer's brand choice and firms' brand performance, as long as they embrace competing brands. In view of this, this study comes up with a validation of a measurement model of Consumer-Based Brand Equity for competing brands of products and services, testing for possible moderation (product / service and experienced / non-experienced consumers).

Method: Appraising 39 brands, the model was composed of 6 metrics: awareness, perceived quality, loyalty, association, exclusiveness and willingness to pay a price premium. Confirmatory factorial analysis revealed the CBBE structure and multigroup moderation tests showed the comparisons between products and services and between experienced and non-experienced consumers.

Main Result: The metrics have convergent validity with very good model fit. The metrics are similar for products / services, but different for consumers with / without experience (evidence of moderation).

Contributions: Based on this measure, researchers and marketers can identify whether their brand's performance has been perceived better or worse than that of their competitors.

Relevance/Originality: This article is the first to offer a more complete scale to assess the consumer-based brand equity of products and services, allowing the researcher to compare the competitiveness between brands.
\end{abstract}

Keywords: Brand Equity. Brand management. Psychometric. Scale. Branding.

\section{VALOR DA MARCA BASEADO NO CONSUMIDOR DE PRODUTOS E SERVIÇOS: AVALIANDO UM MODELO DE MENSURAÇÃO COM MARCAS COMPETIDORAS}

Objetivo: A identificação de qual marca na categoria traz mais ou menos valor para o consumidor suscita dúvidas sobre a composição das medidas de valor e as marcas que compõem a categoria. As medidas para identificação do valor da marca podem abarcar avaliações funcionais para a escolha de marcas dos consumidores e para o desempenho da marca das empresas, desde que inclua marcas competidoras. Em vista disso, o estudo mostra a validação de um modelo de mensuração de Valor da Marca Baseada no Consumidor (VMBC) para marcas concorrentes de produtos e serviços, testando possível moderação (produto / serviço e consumidores experientes / não experientes).

Método: Com 39 marcas sendo avaliadas, o modelo foi composto por 6 métricas: conscientização, qualidade percebida, lealdade, associação, exclusividade e disposição a pagar um preço premium. A análise fatorial confirmatória revelou a estrutura do VMBC e os testes de moderação multigrupos mostraram as comparações entre produtos e serviços e entre consumidores experientes e não experientes.

Principais Resultados: As métricas apresentaram validação convergente com ótimo ajuste do modelo. As métricas são semelhantes aos produtos / serviços, mas diferentes para os consumidores com / sem experiência (evidência de moderação).

Contribuição: Baseada nessa medida, pesquisadores e gestores de marketing podem identificar se o desempenho de sua marca tem sido percebido como melhor ou pior do que os concorrentes.

Relevância/Originalidade: Este artigo é o primeiro a oferecer uma escala mais completa para avaliar o valor de marcas baseada no consumidor de produtos e serviços permitindo o pesquisador comparar a competitividade entre marcas.

Palavras-chave: Valor da Marca. Gestão da Marca. Psicometria. Escala. Branding.

Rafael Barreiros Porto ${ }^{1}$

\footnotetext{
${ }^{1}$ Post Doctor in Marketing at the Cardiff Business School and PhD in Behavioral Science at the University of Brasilia - UnB. Professor of Marketing in PostGraduate Program in Administration from the University of Brasilia - UnB.

Brasília, Brazil. E-mail: rafaelporto@unb.br
} 


\section{INTRODUCTION}

In competitive markets, when consumers evaluate a brand, they do not do so without a comparative basis (Samson \& Voyer, 2014). They compare brands and decide that some are better than others in certain categories. However, the current Consumer-Based Brand Equity (CBBE) scales commonly used in researches may not detect this if a consumer evaluates one or two brands, when there are several brands of the same category on the market (Ehrenberg, Uncles, \& Goodhardt, 2004).

That is, in responding a questionnaire embracing CBBE metrics, consumers can assign an evaluative response (e.g. agreeing that 'This brand is good quality' or 'This brand is consistent quality' or 'This brand has excellent features'). However, if the same consumer evaluates other brands of the same category using the same questionnaire (with the same scale of agreement), they can also give the same response (e.g. strongly agree) to other brands, which raises confounding results: after all, which brand has greater equity (e.g. higher quality)? Disentangling this dubious result may be important in order to predict the brand choice (at a consumer level) and brand performance (at a product level) within competitive markets. This study shows a way to avoid this problem.

Despite the theory of CBBE is well developed at the consumer level (Aaker, 1996; Erdem \& Swait, 2014; Srinivasan, Hsu, \& Fournier, 2011), the measuring instruments of CBBE deal with consumers evaluating brand, but the outcome of such evaluations is the brand equity, another level of analysis. At this level, brands compete to be chosen and this gives them a performance context (Noble \& Basil, 2011). Brand managers usually want to raise brand metrics, using them as performance indexes (Ehrenberg et al., 2004), such as brand share or loyalty rate. So, the brand level of analysis is the right level of giving answers to managers' concerns. As put by Foxall, Wells, Chang e Oliveira-Castro (2010), the brand level of analysis "makes marketing inquiry unique within the social sciences." (p. 145).

Scientific research on CBBE (Keller, 1993; Erdem \& Swait, 2014) lacks a measurement instrument that encompasses several diverse brands of products and services with the ability to avoid dubious responses on brand equity in competitive contexts and capable of leveraging these metrics to the brand level. Current measurements are perhaps diverting from the focus of competitiveness, ignoring the brand level (Tolba \& Hassan, 2009; Wang \& Finn, 2012). That is, claiming that a brand has a high brand equity rating (Lassar, Mittal, \& Sharma, 1995), without considering the ratings of other alternatives in the market, seems to be missing the point of evaluating brand equity in a context that involves rival brands.

Thus, instruments that measure CBBE need to capture 'The Big Picture', being attentive to how consumers evaluate substitutable brands (Davcik, Vinhas da Silva, \& Hair, 2015) and taking this to the higher level of brand performance. In this sense the evaluation of brands must be considered more closely to the reality of the markets and, if these are considered, CBBE research could get in the field of brand choice and brand performance (Foxall et al., 2010; Uncles, Kennedy, Nenycz-Thiel, Singh, \& Kwok, 2012).

The current research proposes and demonstrates the confirmatory factorial validity of a CBBE measurement model for competing brands of products and services, applied to consumer level, but aggregating the scores to the brand level of analysis. This includes several substitute brands (all existing in the market surveyed) with different measurement scales created through six metrics: awareness, perceived quality, image association, loyalty, willingness to pay a price premium and exclusiveness.

In addition, brand equity indexes could be divergent for products and services (Christodoulides, Cadogan, \& Veloutsou, 2015) and could be very differently evaluated whether or not consumers know the brands they are stimulated to be given a response (Erdem et al., 1999). Therefore, complementarily, this research shows two Multigroup Moderation Tests comparing product versus service and experienced versus inexperienced consumers. Tests that control these effects can resolve these doubts and allow a more scientific generalization [e.g. finding 'law like' (Hunt, 2010)] to establish a purpose for use by practitioners.

Since it is a measurement that refers to brand competitiveness, a CBBE index can illustrate the ranking of brands (Chu \& Keh, 2006), showing those that indicate a higher impact from branding activities versus those that have not received as much activity. Therefore, as a final objective, the study aimed to demonstrate a ranking based on the structure of CBBE. It is hoped that the alternative measure for CBBE of products and services that has been validated here may be useful to marketing researchers, so as to evaluate the performance of brands and to detect brand choices made by consumers.

The article initially presents a theoretical review contextualizing the theory of $\mathrm{CBBE}$ by Operant Behavioral Economics, arguing that current measures of CBBE need to capture the competitiveness between brands by the perception of consumers. Next, it presents the research method, with an instrument that captures this 
competitiveness. Then it shows the research results divided into three parts: (1) factorial validation of the CBBE measurement model, (2) moderation test of product vs. service and experienced consumers vs. non experienced consumers and (3) finally a ranking of brands with greater / lesser equity. The discussion section presents the benefit of this model with the scales tested to identify the competitiveness of the brands in each CBBE metric. Throughout the final considerations it shows the benefits of using this CBBE measurement model and its limitation.

\section{The Added Value of Consumer-Based Brand Equity}

Although there is no universally accepted definition of brand equity (Christodoulides \& De Chernatony, 2010), it is established that it is the added value endowed by the brand to the product (Christodoulides, 2015; Farquhar, 1989). However, unless there are more detailed explanations, the definition of what constitutes an 'added value' does not clarify what the concept of brand equity actually means. Using the product value classification based on Operant Behavioral Economics (Foxall, 2015) may serve to help clarify this concept.

Smith (1784) describes how the exchange of goods involves two type of value: value in use and value in exchange. The first refers to the use of a product/service, what can be done with it. At brand level (Oliveira-Castro, Foxall, Yan, \& Wells, 2011), the value in use means that a consumer handles a brand from a manufacturer or receives services from a supplier in order to obtain some form of benefit (e.g. learning derived from didactic teaching activities in a brand $X$ education service).

In turn, the value in exchange refers to the purchasing power that the said brand product (or service) owns (Oliveira-Castro, Foxall, \& Wells, 2010), in relation to other brands of products/services. This second value requires economic/social exchanges that are at the core of the marketing concept (Foxall, 1999). This exchange can be directed forwards (e.g. an exchange of money paid by the consumer to the company and by the company that delivers products to the consumer) or lateral exchange [e.g. the exchange of one brand for another by the consumer (brand choice) or the exchange of one brand for another by the company (investment in a brand portfolio)].

The Firm-Based Brand Equity [FBBE] (Christodoulides \& De Chernatony, 2010) adopts the perspective of supply. The added value represents company benefits that result from the exchange of a certain brand within the consumer market. That is to say, these are the benefits that brand marketing activities enable a company to receive, usually in the form of revenue, profits, margins, shareholder value, and so on. On the other hand, Consumer-Based Brand Equity assumes the perspective of demand (Oliveira-Castro, Foxall, James, Pohl, Dias, \& Chang, 2008). Thus, when an exchange takes place, a CBBE added value refers to what benefits a brand can bring to a consumer that are greater than those offered by a rival brand.

In this sense, a CBBE is a measurement of brand competitiveness with regards to the consumer benefits attached to each brand, that result from economic/social exchanges. When a consumer decides that a brand is more equitable than another (e.g. has more quality, is better known and someone is willing to pay more for this brand above any other), the consumer is deciding that a particular brand will bring him or her more economic and social benefits than any other brand. In other words, the consumer is saying: it is worth more to acquire this brand (forward exchange) than any other brand (lateral exchange). Nonetheless, the specific benefits that consumers are acquiring in this exchange are not explicit in the $\mathrm{CBBE}$ measurements, but merely indicated or inferred.

The brand evaluative process implies understanding the purpose of the brand choices made by consumers - what are consumers gaining when they attribute a higher score to one brand over another. Contextualizing the purchase of a brand during the course of a behavioral chain, OliveiraCastro et al. (2011) suggest that brands indicate the value in exchange through a symbolic way and the value in use through utilities, and that both combine to produce many real choices of products and services. In this sense, the brands that bring greater social-economic benefits (Foxall, 2015) than any other brand (value in exchange) can also bring social status, fulfillment, accomplishment, sophistication, exclusivity, social approval if these are also paired to the utilitarian benefits of these same brands (value in use).

This is due to the fact that brands bring symbolic benefits through social environments mediation and bring utilitarian benefits through the mediation of using product attributes or service. For example, a car brand that, once purchased, promotes social power, needs a social environment of approval (to be displayed by the consumer within a sector of society such as work colleagues, family, friends, etc.), as well as some efficient attributes of the product when in use. Thus, brands that bring a greater degree of symbolic and utilitarian benefits need to be very well known, to be of high quality, to be more expensive, and so on. The CBBE are therefore the sources of the choices that lead to these benefits.

When responding to measurement instruments, the CBBE responses show the brands that are worth consumers using and paying money 
for (even though this may involve an imaginary situation). In other words, the brands that consumers perceive (1) as being more familiar, (2) that are of better quality, (3) that they describe as representing greater brand loyalty, (4) that they are willing to pay more for, (5) that they feel are more exclusive or (6) which they associate with positive aspects of some kind, are those that are worth more to them when they make their brand choices above any other. In the case of a lateral exchange (brand choice), these are the brands that a consumer perceives as offering more economic-social benefits, matched with their value in use. Thus,

H1: The metrics of awareness (familiarity), perceived quality, image association, loyalty, exclusiveness and willingness to pay a price premium have convergent validity in ConsumerBased Brand equity construct.

\section{Opportunities for a New Cbbe Measurement Model}

Although several measurement instruments appraising the CBBE are easily applied (Lehmann, Keller, \& Farley, 2008), many of them do not simultaneously examine numerous brands by instruments. They ascertain whether or not a brand name of a particular category presents brand equity, based on the responses given by consumers according to the Likert scale (usually scale of agreement). Establishing several brands at the same time enhances the substitutability between brands. This can be helpful in predicting consumer choices (Foxall et al., 2010) and detect brand performance (Porto \& Oliveira-Castro, 2015).

When adopting a metric capable of comparing several brands and aggregating them to the brand level of analysis, this provides an opportunity to identify the brand equity of all brands in a category, including the smaller brands. These are very often not included in scientific investigations on CBBE, even though consumers occasionally choose them (Ehrenberg et al., 2004). The absence of such information makes it impossible to establish the ranking of brands belonging to the same category (Chu \& Keh, 2006) with metrics developed by scholars. The inclusion of smaller brands makes it possible to clarify those that have greater equity (Davcik et al., 2015). Thus, a measurement that covers smaller brands can improve the prediction of brand choice and their performance, thereby increasing the management utility of the measurement.

Furthermore, one of the great questions that have not been resolved is if the metrics of the CBBE measurements are valid both for products and services (Christodoulides et al., 2015). This is possibly due to the fact that there is no systemization of findings that refer to the way that brands are evaluated by the consumer using a questionnaire, as well as the brand market structures (Porto \& Oliveira-Castro, 2015) in each region. If in competitive markets there are options for a possible choice (Foxall et al., 2010), the metrics of the CBBE should not change between products and services, since these are classified as very generic (category level). But they should change between brands within a category, since the precedents (e.g. brand recall, use experience) and outcomes (e.g. fulfillment, accomplishment, etc.) of the brand choices are very different. Then,

H2: The metrics of Consumer-Based Brand Equity do not differ significantly if the brands belong to categories of products or services.

Though, the evaluations that consumers make about a brand in competitive markets should change if consumers have or do not have brand experience with the available choice options in a category (Erdem et al., 1999). Consumers who have no experience with some of the brand alternatives (either products or services) can overestimate (or underestimate) the evaluation for each brand (Oliveira-Castro et al., 2008). However, if one category has more inexperienced consumers (e.g. in brand launch period featuring a new category or categories of less frequent purchases), the information asymmetry resulting from their lack of experience (Erdem \& Swait, 1998) may distort the evaluations with regards to the brand choice itself. Therefore,

H3: The experience with the brand moderates the metrics weights to make up the Consumer-Based Brand Equity Construct.

The measurement instruments related to CBBE that (1) do not simultaneously measure various competing brands, (2) do not also consider the equity of smaller brands, (3) do not aggregate the consumers' responses to the brand level of analysis, (4) that do not compare brand products and services simultaneously, and (5) that do not consider consumer experience with brands in a category, thereby lose the opportunity to be of use to brand managers. They miss the chance to show which brands are already being considered for choices, showing those that would bring greater socialeconomic benefits for the consumer who evaluates them. This research offers a measurement model capable of encompassing competing brands and many CBBE metrics in an effort to overcome the limitations mentioned above. 


\section{METHOD}

\section{Sample}

The research has a cross section design. Consumers evaluated 39 brands related to two products (isotonic beverages and videogame consoles), and five services (land transportation (taxis), pay-per-view cable TV subscription systems, mobile telephone operators, credit card financial services and fast food restaurants). Fast food restaurants were treated as a service (Jara \& Cliquet, 2012), because this provides a retail food service for consumers.

The products were chosen due to their variety of uses as routine purchase products/services (e.g. fast food hamburger and sandwich restaurants, payper-view cable TV), as well as less frequently purchased products/services (e.g. land transportation, videogame consoles).

It should be emphasized that this research includes major sales brands (e.g. Visa ${ }^{\circledR}$, McDonald's $\left.{ }^{\circledR}\right)$, intermediary brands (e.g. American Express ${ }^{\circledR}$, Burger King $\left.®\right)$, and small brands in terms of sales or even local brands (e.g. Aura ${ }^{\circledR}$, Bob's ${ }^{\circledR}$ ), thereby guaranteeing a sampling of those brands that compete amongst themselves in each category within a certain location.

In all, 1.092 real consumers responded to the instrument containing all the metrics. The sample power for Confirmatory Factor Analysis with 9 degrees of freedom is $88.3 \%$, a good parameter to avoid Error 2 Type. In general terms, the respondents had acquired at least one credit card between 2010$2015(82.0 \%)$; had paid for land transport services (taxis) at least once during the year of 2015 (54.0\%); had bought snacks at a fast food restaurant at least once a month (87.9\%); had acquired pay-per-view cable TV services between 2010-2015 (84.2\%); had acquired at least one videogame console between 2005-2010 (89.6\%); only $11 \%$ said they had bought isotonic beverages once a month, and most of the consumers had changed their mobile phone operators between 2010-2015 (64.4\%).

\section{Instrument and data collection}

The research instrument is formed by 6 metrics (awareness, perceived quality, loyalty, association, exclusiveness and willingness to pay a price premium). The question and response scales can be seen on Table 1. The scale of Awareness and Perceived quality were based on the work of Oliveira-Castro et al. (2008), which established one metric capable of supporting large and small brands. A minor adjustment was made to the Perceived quality metric in order to codify in 0 and insert 'no quality', as well as to the Awareness metric, while one further codification (quite well known) was added.

The Association metric was inspired by the proposal of Keller (2003), although this was adapted for a valence scale of image (varying between a very negative image and a very positive image), with the use of logos, as a means of encouraging consumers to remember a brand name. This metric has an openended response scale, making it possible for the respondent to insert the first two words or images that come to mind (using a maximum of 2 words) that represent the brand.

For example, in the isotonic beverage category, the word that was most representative of the Gatorade ${ }^{\circledR}$ brand name was 'energy' $(20.2 \%)$; the word 'marathon' for the Marathon ${ }^{\circledR}$ brand name $(10.1 \%)$; the word 'blue' for the Powerade ${ }^{\circledR}$ brand name $(6.2 \%)$; the word 'water' for the i9 brand (4.3\%); and 'Pão de Açucar®', the name of a supermarket chain, was the most representative term used for the Taeq® brand name $(4.2 \%)$. The brand with the highest absence of brand recall in this category was Marathon (59.2\%).

This metric was later codified using a valence image scale. Thus, terms that had a negative slant (e.g. bad, last options, gastritis (illness), that reminded consumers of a rival brand) were codified as being negative, while terms that had a positive slant and/or reminded consumers of advertising material related to the brand evaluated (e.g. appetizing, delicious, particular piece of the commercial) were codified as being positive. All the others that did not fit these two options were codified as being neutral.

Loyalty was constructed based on the finding of Ehrenberg et al. (2004) that shows that the purchase frequency of each brand is a measure of behavioral loyalty. However, in the case of this research, this is a verbal reporting measurement that assures the volume of buying different brands. This scale represents the discrepancies that exist between the high/low frequency purchases for different brands, adapted over a period of time (weeks, months or years).

Willingness to pay a price premium was based on the work of Netemeyer et al. (2004), which justifies this measure because branding activities very often aim to encourage consumers to pay higher prices than they would for a product without a brand name. However, in this research, this measure was adapted so that the consumer could, in effect, state the price he or she would be willing to pay for a standard product and services configuration. Thus, consumers could type the most expensive selling price they would pay for that brand product or service. The unit of measurement is customized for each category of product/service. 
For example, in the case of videogame console, the average maximum price that a consumer think people would pay for a Playstation 4® console would be around $\$ 463.75$ (Low Bound $=\$ 399.5$ and Upper Bound $=\$ 528.0$ of $95 \%$ Confidence Interval), when the average sales price for this brand is $\$ 350.0$. In the case of a console under the Xbox ${ }^{\circledR}$ brand, the average maximum price was in the order of $\$ 428.22$ (Low Bound $=\$ 364.0$ and Upper Bound $=\$ 492.5$ of 95\% Confidence Interval) when the average sales price for this brand is $\$ 400.0$. In the case of a
Nintendo Wii ${ }^{\circledR}$ console the average maximum price was $\$ 310.0$ (Low Bound $=\$ 245.8$ and Upper Bound $=\$ 374.3$ of $95 \%$ Confidence Interval) when the average sales price for this brand is $\$ 300.0$.

The Exclusiveness metric was guided on the work of Keller (1993). This was included due to the assumption that consumers may consider some brands to be exclusive (providing symbolic benefits). The response scale was created to enable the respondent to decide between one extreme (not exclusive at all) and the other (very exclusive).

Table 1 - Scale of CBBE for products and services.

\begin{tabular}{|c|c|c|}
\hline Brand metrics & Question & Response scale and codification $^{a}$ \\
\hline Awareness & $\begin{array}{l}\text { From the list of brands below, evaluate how well } \\
\text { each brand of product/service is known }\end{array}$ & $\begin{array}{l}0 \text { (not known at all), } 1 \text { (known a little), } 2 \\
\text { (moderately known), } 3 \text { (quite well known) } \\
\text { and } 4 \text { (very well known) }\end{array}$ \\
\hline $\begin{array}{l}\text { Association } \\
\text { (image) }\end{array}$ & $\begin{array}{l}\text { From the list of brands below, what are the first two } \\
\text { words or images that come to mind for each brand } \\
\text { of product/service }\end{array}$ & $\begin{array}{l}0 \text { (very negative association), } 1 \text { (negative } \\
\text { association), } 2 \text { (neutral), } 3 \text { (positive } \\
\text { association) and } 4 \text { (very positive } \\
\text { association) }\end{array}$ \\
\hline Perceived quality & $\begin{array}{l}\text { From the list of brands below, evaluate the quality } \\
\text { of each brand of product /service }\end{array}$ & $\begin{array}{l}0 \text { (very low quality), } 1 \text { (low quality), } 2 \\
\text { (medium quality), } 3 \text { (high quality) and } 4 \\
\text { (very high quality) }\end{array}$ \\
\hline Loyalty & $\begin{array}{l}\text { From the list of brands below, what is your purchase } \\
\text { volume for this product / service? }\end{array}$ & $\begin{array}{l}0 \text { (zero), } 1 \text { (from } \underline{1} \text { unit per week, month or } \\
\text { year to } \underline{2} \text { units per week, month or year), } 2 \\
\text { (from } \underline{3} \text { units per week, month or year to } \underline{4} \\
\text { units per week, month or year), } 3 \text { (from } \underline{5} \\
\text { units per week, month or year to } \underline{6} \text { units per } \\
\text { week, month or year) and } 4 \text { (above } \underline{6} \text { units } \\
\text { per week, month or year) }\end{array}$ \\
\hline Exclusiveness & $\begin{array}{l}\text { From the list of brands below, evaluate the } \\
\text { exclusiveness that each brand appears to generate } \\
\text { for people who buy this product/service? }\end{array}$ & $\begin{array}{l}0 \text { (not exclusive at all), } 1 \text { (little bit } \\
\text { exclusive), } 2 \text { (moderately exclusive), } 3 \\
\text { (kind of exclusive) and } 4 \text { (very exclusive) }\end{array}$ \\
\hline $\begin{array}{l}\text { Willingness to pay } \\
\text { a price premium }\end{array}$ & $\begin{array}{l}\text { From the list of brands below, what would be the } \\
\text { highest price you would pay for a unit (or a monthly } \\
\text { fee or by the passage from from each } \\
\text { brand of this product / service? }\end{array}$ & $\$$ \\
\hline
\end{tabular}

Example: From the list of brands below, evaluate how well each brand of fast food hamburger or sandwich restaurant is known:

\begin{tabular}{|c|c|c|c|c|c|c|}
\hline Brands & $\begin{array}{l}\text { Not known } \\
\text { at all }\end{array}$ & $\begin{array}{l}\text { Known a } \\
\text { little }\end{array}$ & $\begin{array}{l}\text { Moderately } \\
\text { known }\end{array}$ & $\begin{array}{l}\text { Quite well } \\
\text { known }\end{array}$ & $\begin{array}{l}\text { Very well } \\
\text { known }\end{array}$ & $\begin{array}{c}\text { I do not know } \\
\text { how to } \\
\text { evaluate this } \\
\text { brand }\end{array}$ \\
\hline Bob’s® & 0 & 0 & 0 & 0 & $\circ$ & 0 \\
\hline Burger King $®$ & 0 & 0 & 0 & 0 & 0 & 0 \\
\hline Giraffa's® & 0 & 0 & 0 & 0 & o & 0 \\
\hline Habib’s® & 0 & o & o & 0 & 0 & 0 \\
\hline McDonald's® & o & 0 & o & 0 & o & 0 \\
\hline Subway® & 0 & 0 & $\circ$ & 0 & $\circ$ & 0 \\
\hline
\end{tabular}

${ }^{a}$ the brand names were arranged with items to be evaluated placed in alphabetical order. If the respondent did not know how to evaluate a certain brand, he was given the option to click on the item: I do not know how to evaluate this brand;

${ }^{\mathrm{b}}$ Association had an open-ended response scale for each logo shown. This was included in the online questionnaire so that respondents could type in a maximum of two words. The scales were codified once a content analysis had been conducted. Respondents who wrote two negative (positive) words were classified as having a very negative 
(or very positive) association. If respondents wrote one negative word (positive) and another neutral, words were classified as having little bit negative (positive) association. If they wrote only neutral words or one negative and one positive word, they were classified as being neutral. If the respondent did not remember any word (or image), he/she was asked to click on 'I don't remember any word or image'. All terms were codified according to scale. ${ }^{\mathrm{c}}$ This scale needs to be customized for each product/service.

${ }^{\mathrm{d}}$ This scale was designed so that a respondent could only insert a positive numerical value or zero. Source: Prepared by the authors.

In the case of all metrics, all the brands (and scales of responses) of each product/service were listed in the questionnaire after each question. This made it possible to obtain the same measurement for each brand of the same product/service and to make a comparison between them. The questionnaire was made available via the internet using an online platform and publicized on social network links in Brazil. On average, it took each respondent 4 minutes (S.D. $=1.2$ ) to complete all the questions for each product/service. It took 15 days to gather this information from all the consumers involved.

\section{Data analysis}

The Awareness metric presented an average of 1.64 (S.D. = 0.7); the Perceived quality metric showed an average of 2.25 (S.D. = 0.8); the Image association metric presented an average of 2.13 (S.D. $=0.3$ ); the Loyalty metric presented an average of 0.65 (S.D. = 0.5); the Exclusiveness metric presented an average of 1.26 (S.D. $=0.7$ ), while the Willingness to pay a price premium metric showed an average of $\$ 218.62$ (S.D. $=632.9$ ).

Since the metrics have different scales, all the measurements were relativized (divided by the average of each category) before each analysis was carried out. Thus, when a value was equal to 1 , the metric was equal to the category average. Values below 1 (or above 1) were those below the average (above the average). All data analysis was conducted after this transformation was made.

For the brand-level analysis procedure, the database was restructured (lines versus columns), the data of consumers' responses were aggregated per brand and 10 multivariate outliers were eliminated by means of the Mahalanobis Distance test, attaining 1.082 cases. The data does not have a normal multivariate distribution (Mardia's Coefficient $=75$; Critical Ratio $=233.9$ ), and, as a result, in the confirmatory factorial analysis and moderation tests, the Maximum Likelihood Estimation was used, which is a good test for violations of normality assumptions (Marcoulides \& Schumacker, 2013).

In both moderation analyses, a Multigroup comparison was made based on the Zscore test, using two groups: products versus services and experienced consumers versus inexperienced consumers as moderators. The ranking was established using a standard CBBE score index as a dependent variable and brands as independent variables in an Analysis of Variance (ANOVA), with a Tukey Post-Hoc Test.

\section{RESULTS}

The results are shown in three sections. Initially, the author showed the measurement model validation with the final model appraising the metrics of CBBE. Subsequently, two moderation tests (multigroups) made it possible to demonstrate the breadth of the final version of the scale. Finally, the author established a ranking with the use of Analysis of Variance (ANOVA), based on the standardized CBBE score index.

\section{CBBE measurement model validation}

The database was initially divided into two sub-samples (split sample of 50\%) in order to produce the Confirmatory Factor Analysis results (the two final columns shown on Table 2). In each of the analyses, the factor loading, the Composite Reliability (CR), Average Variance Extracted (AVE) and all the model adjustment indicators are very satisfactory and similar to one another.

This was then followed by an analysis of the total sampling. With $\mathrm{KMO}=0.81(\mathrm{p} \leq 0.01)$, all the Factor loadings were satisfactory, showing that $\mathrm{CBBE}$ is unifactorial with the six metrics used: Perceived quality, Awareness, Loyalty, Association, Willingness to pay a price premium and Exclusiveness. The Composite Reliability exceeded the level suggested by Hair, Black, Babin, and Anderson (2013) (CR > 0.70), presenting a value at 0.87 , and The Average Variance Extracted (AVE) exceeded the reference limit (AVE > 0.50) suggested by Hair et al. (2013), presenting a value of 0.55 . That is to say, there was a convergent validity of the six metrics for a CBBE construct.

The Modification Indices (MI) show that there is no problem with the covariance among the items (the greatest MI value index was for MI association and exclusivity $=0.32$ ). This means that items are discriminatory amongst themselves. In addition, the Inter-item Correlation is shown to be adequate $($ Mean $=0.40 ;$ Standard Deviation $=0.16$ ), in accordance with the homogeneity parameters 
proposed by Clark and Watson (1995). This means that the items are not redundant in the onedimensional structure. They do not even belong to another construct. The Model shows an excellent fit with Chi square $=223.58(\mathrm{p} \leq 0.01), \mathrm{TLI}=0.95$, GFI
$=0.98$, RMSEA $=0.08$ and $\mathrm{SRMR}=0.04$. The values of these indicators show that these metrics belong to the same construct and are reliable, corroborating H1.

Table 2 - Model fit of CBBE measurement model

\begin{tabular}{|c|c|c|c|c|c|c|}
\hline \multirow[b]{2}{*}{ Brand metrics } & \multicolumn{4}{|c|}{ Total sample } & \multirow{2}{*}{$\begin{array}{c}\text { Sub sample } 1 \\
\begin{array}{c}\text { Factor } \\
\text { loading }\end{array}\end{array}$} & \multirow{2}{*}{$\begin{array}{c}\text { Sub sample } 2 \\
\begin{array}{c}\text { Factor } \\
\text { loading }\end{array}\end{array}$} \\
\hline & $\begin{array}{l}\text { Factor } \\
\text { loading }\end{array}$ & $\begin{array}{c}\text { Principal } \\
\text { component }\end{array}$ & $\begin{array}{c}\text { Relative } \\
\text { mean }\end{array}$ & $\begin{array}{l}\text { Standard } \\
\text { deviation }\end{array}$ & & \\
\hline Perceived quality & 0.88 & 0.87 & 1 & 0.79 & 0.85 & 0.89 \\
\hline Awareness & 0.87 & 0.86 & 1 & 0.80 & 0.87 & 0.87 \\
\hline Loyalty & 0.72 & 0.79 & 1 & 1.38 & 0.73 & 0.70 \\
\hline Exclusiveness & 0.57 & .0 .69 & 1 & 0.98 & 0.52 & 0.60 \\
\hline $\begin{array}{l}\text { Willingness to pay a } \\
\text { price premium }\end{array}$ & 0.43 & 0.57 & 1 & 0.53 & 0.48 & 0.42 \\
\hline Association (image) & 0.33 & 0.33 & 1 & 0.48 & 0.29 & 0.30 \\
\hline $\begin{array}{l}\text { Variance explained } \\
\text { KMO }\end{array}$ & & $\begin{array}{c}50.3 \% \\
0.81(\mathrm{p}<0.01)\end{array}$ & & & & \\
\hline $\begin{array}{l}\text { Composite reliability } \\
\text { (CR) }\end{array}$ & 0.87 & & & & 0.86 & 0.87 \\
\hline $\begin{array}{l}\text { Average variance } \\
\text { extracted (AVE) }\end{array}$ & 0.55 & & & & 0.53 & 0.55 \\
\hline Chi square & $\begin{array}{c}223.58 \\
(\mathrm{p} \leq 0.01)\end{array}$ & & & & $\begin{array}{c}99.22 \\
(\mathrm{p} \leq 0.01)\end{array}$ & $\begin{array}{c}116.97 \\
(\mathrm{p} \leq 0.01)\end{array}$ \\
\hline GFI & 0.98 & & & & 0.98 & 0.97 \\
\hline AGFI & 0.95 & & & & 0.94 & 0.93 \\
\hline CFI & 0.97 & & & & 0.97 & 0.96 \\
\hline TLI & 0.95 & & & & 0.94 & 0.94 \\
\hline RMSEA & 0.08 & & & & 0.08 & 0.09 \\
\hline SRMR & 0.03 & & & & 0.03 & 0.04 \\
\hline
\end{tabular}

Source: Prepared by the authors.

Figure 1 shows the final model with the standard Factor Loadings and explained variance described for each metric. It should be emphasized that some preliminary models were drawn up. One of these contains two dimensions (dimension 1: Awareness, Perceived quality and Loyalty and dimension 2: Exclusiveness, Willingness to pay a price premium and Association), but do not present discriminant - in accordance with the Fornell Lacker Test - validity (Hair, Black, Babin, \& Anderson., 2013).
Another preliminary model eliminating the Association metric was carried out and remained unifactorial. This model presented slightly better adjustment indicators, with an even better convergent validity. However, due to the qualitative and theoretical contribution of the Association metric in the consumer's language to see the brand image that was actually perceived (the first two words or images that come to mind), it was decided to retain it in the final model, but still with good adjustments and convergent validity. 


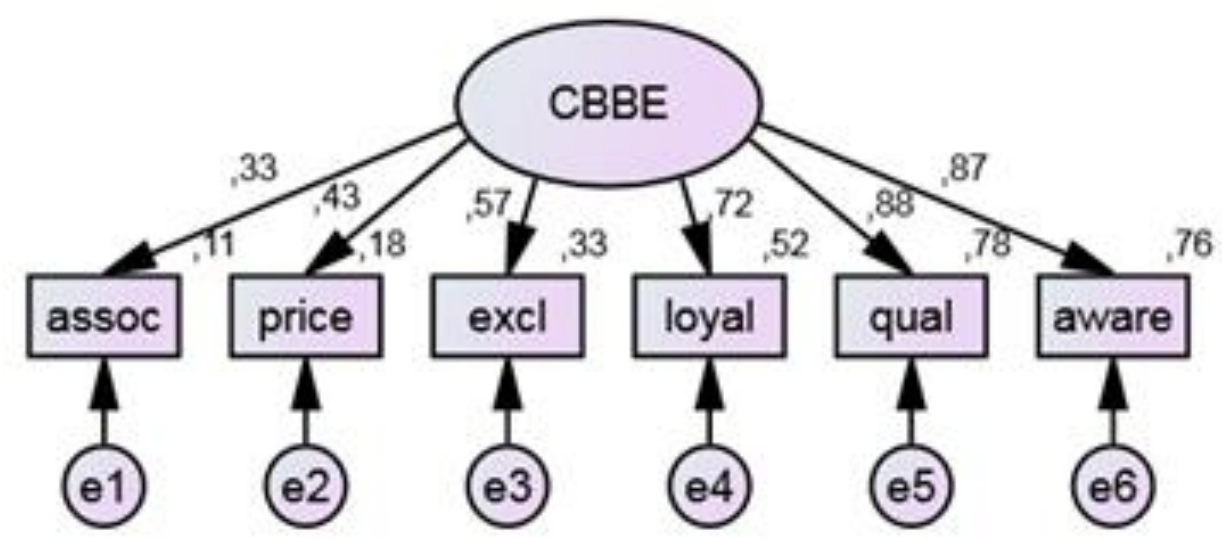

Figure 1 - Unifactorial solution derived from the CBBE Source: Prepared by the authors.

\section{Test of moderation}

Two tests of moderation were conducted by using multi-groups. The first compared the nonstandard score estimates between products and services (Table 3). The second test (Table 4) compared the non-standard test estimates between experienced consumers (those who had with some frequency and recently purchased the product/service) and inexperienced consumers (those who had not bought the products/services).

In the product/service moderation test, the Zscore did not achieve significance $(\mathrm{p}>0.05)$ in all the metrics, corroborating $\mathrm{H} 2$. There is no significant difference in the comparison made between these metrics and the brand products/services investigated. This indicates that it is possible to compare (and rank) all the brands investigated, even though those that belong to different categories.

Table 3 - Moderation of product versus service for CBBE metrics

\begin{tabular}{|c|c|c|c|c|c|c|c|}
\hline \multirow{2}{*}{\multicolumn{3}{|c|}{ Multigroup Test 1}} & \multicolumn{2}{|c|}{ Product } & \multicolumn{2}{|c|}{ Service } & \multirow[b]{2}{*}{ z-score ${ }^{a}$} \\
\hline & & & Estimate & p value & Estimate & p value & \\
\hline Perceived quality & $\leftarrow$ & CBBE & 0.92 & 0.00 & 0.95 & 0.00 & 0.71 (n.s) \\
\hline Awareness & $\leftarrow$ & CBBE & 1.05 & 0.00 & 1.08 & 0.00 & 0.71 (n.s) \\
\hline Loyalty & $\leftarrow$ & CBBE & 8.05 & 0.00 & 10.12 & 0.00 & 1.46 (n.s) \\
\hline Exclusiveness & $\leftarrow$ & CBBE & 0.81 & 0.00 & 0.89 & 0.00 & 1.21 (n.s) \\
\hline Willingness to pay a price premium & $\leftarrow$ & CBBE & 1.88 & 0.00 & 2.39 & 0.00 & 1.44 (n.s) \\
\hline Association (image) & $\leftarrow$ & $\mathrm{CBBE}$ & 0.53 & 0.00 & 0.42 & 0.00 & -1.44 (n.s) \\
\hline
\end{tabular}

Notes: $* * *$ p-value $\leq 0.01 ; * *$ p-value $\leq 0.05 ; *$ p-value $\leq 0.10$

a: n.s. - not significant

Source: Prepared by the authors.

In experience moderation test, o Z-score achieved significance in all the metrics, corroborating $\mathrm{H} 3$. With the exception of the Awareness metric, all the other metrics are more accentuated for experienced consumers rather than for inexperienced consumers. That is to say, experienced consumers seem better able to discriminate between the brands in each of the remaining metrics (Perceived quality, Loyalty, Exclusiveness, Willingness to pay a price premium and Association). The reasons why the Awareness metric was far stronger for consumers with no experience, is probably because they may have underestimated why a certain brand is unknown when they know little about the category as a whole.

Therefore, an evaluation should be made about how experienced respondents are to assign consumer-based brand equity and eliminate respondents without experience, so as not to risk distorting the results. 
Table 4 - Moderation of experienced versus non-experienced consumers for CBBE metrics

\begin{tabular}{|c|c|c|c|c|c|c|c|}
\hline \multirow{2}{*}{\multicolumn{3}{|c|}{ Multigroup Test 2}} & \multicolumn{2}{|c|}{ With experience } & \multicolumn{2}{|c|}{ Without experience } & \multirow[b]{2}{*}{ z-score } \\
\hline & & & Estimate & p value & Estimate & p value & \\
\hline Perceived quality & $\leftarrow$ & CBBE & 0.95 & 0.00 & 0.85 & 0.00 & $-2.36 * *$ \\
\hline Awareness & $\leftarrow$ & CBBE & 1.06 & 0.00 & 1.18 & 0.00 & $2.17 * *$ \\
\hline Loyalty & $\leftarrow$ & CBBE & 1.41 & 0.00 & 0.63 & 0.00 & $-13.30 * * *$ \\
\hline Exclusiveness & $\leftarrow$ & CBBE & 0.78 & 0.00 & 0.64 & 0.00 & $-2.98 * * *$ \\
\hline Willingness to pay a price premium & $\leftarrow$ & CBBE & 0.33 & 0.00 & 0.27 & 0.00 & $-2.81 * * *$ \\
\hline Association (image) & $\leftarrow$ & CBBE & 0.15 & 0.00 & 0.10 & 0.00 & $-1.85^{*}$ \\
\hline
\end{tabular}

Notes: $* * *$ p-value $\leq 0.01 ; * *$ p-value $\leq 0.05 ; *$ p-value $\leq 0.10$

Source: Prepared by the authors.

\section{Rank of consumer-based brand equity index}

The ANOVA test was conducted containing the standardized factor score of CBBE as a dependent variable and brands as independent variables. This made it possible to establish a ranking of the brand products and services. The test attained significance $[\mathrm{F}(38,3681)=128.85 ; \mathrm{p} \leq$
0.01), with a moderate Partial Eta Squared (57.1\%). The (Tukey) Post-Hoc Test showed that 51.3\% of the comparisons made between brands are of significance $(p \leq 0.05)$. Table 5 shows the Estimated Marginal Means of CBBE index, the Standard Error and the Lower and Upper bound of Confidence Interval for each brand from each category.

Table 5 - Estimated marginal means of CBBE index

\begin{tabular}{|c|c|c|c|c|c|}
\hline \multirow{2}{*}{ Category } & \multirow{2}{*}{ Brand } & \multirow{2}{*}{ Mean } & \multirow{2}{*}{ Std. Error } & \multicolumn{2}{|c|}{ Confidence Interval (95\%) } \\
\hline & & & & Lower Bound & Upper Bound \\
\hline \multirow{5}{*}{ Cable Tv } & Net® HDTV & 1.05 & 0.06 & 0.93 & 1.18 \\
\hline & Sky® HDTV & 0.66 & 0.06 & 0.54 & 0.79 \\
\hline & Oi® HDTV & -0.23 & 0.08 & -0.39 & -0.07 \\
\hline & GVT Vivo® HDTV & -0.33 & 0.06 & -0.46 & -0.21 \\
\hline & Claro® HDTV & -0.69 & 0.06 & -0.82 & -0.57 \\
\hline \multirow{8}{*}{ Credit Card } & Visa ${ }^{\circledR}$ & 1.80 & 0.06 & 1.68 & 1.93 \\
\hline & Mastercard® & 1.38 & 0.06 & 1.26 & 1.51 \\
\hline & American Express ${ }^{\circledR}$ & 0.43 & 0.06 & 0.31 & 0.56 \\
\hline & Elo® & -0.26 & 0.07 & -0.39 & -0.13 \\
\hline & Diners Club® & -0.29 & 0.06 & -0.42 & -0.17 \\
\hline & Hipercard $®$ & -0.73 & 0.06 & -0.86 & -0.61 \\
\hline & Aura ${ }^{\circledR}$ & -1.16 & 0.06 & -1.29 & -1.04 \\
\hline & Sorocred ${ }^{\circledR}$ & -1.18 & 0.06 & -1.31 & -1.06 \\
\hline \multirow{6}{*}{$\begin{array}{l}\text { Fast food } \\
\text { hamburger and } \\
\text { sandwich } \\
\text { restaurant }\end{array}$} & Subway® & 0.41 & 0.05 & 0.31 & 0.52 \\
\hline & Mc Donald's® & 0.39 & 0.05 & 0.29 & 0.50 \\
\hline & Burger King® & 0.02 & 0.05 & -0.09 & 0.12 \\
\hline & Giraffa's® & -0.08 & 0.06 & -0.19 & 0.03 \\
\hline & Habib's® & -0.37 & 0.06 & -0.48 & -0.26 \\
\hline & Bob's® & -0.39 & 0.05 & -0.50 & -0.29 \\
\hline \multirow{5}{*}{ Isotonic beverage } & Gatorade ${ }^{\circledR}$ & 1.11 & 0.08 & 0.95 & 1.28 \\
\hline & Powerade $\AA$ & 0.35 & 0.08 & 0.19 & 0.51 \\
\hline & $\mathrm{I} 9 \circledR$ & -0.33 & 0.08 & -0.50 & -0.17 \\
\hline & Taeq ${ }^{\circledR}$ & -0.48 & 0.08 & -0.64 & -0.32 \\
\hline & Marathon ${ }^{\circledR}$ & -0.65 & 0.08 & -0.81 & -0.48 \\
\hline \multirow{5}{*}{ Mobile service } & Tim $\AA$ mobile & 0.24 & 0.08 & 0.09 & 0.39 \\
\hline & Claro $®$ mobile & 0.23 & 0.08 & 0.08 & 0.38 \\
\hline & Vivo ${ }^{\circledR}$ mobile & 0.08 & 0.07 & -0.05 & 0.22 \\
\hline & Nextel ${ }^{\circledR}$ mobile & -0.45 & 0.08 & -0.62 & -0.29 \\
\hline & Oi® mobile & -0.69 & 0.06 & -0.81 & -0.56 \\
\hline \multirow{6}{*}{ Taxi } & Uber® & 2.66 & 0.09 & 2.49 & 2.84 \\
\hline & Easy Taxi ${ }^{\circledR}$ & 0.78 & 0.09 & 0.60 & 0.96 \\
\hline & $99 \operatorname{taxis} ®$ & 0.51 & 0.09 & 0.33 & 0.69 \\
\hline & Vá de táxi® & -0.91 & 0.09 & -1.09 & -0.73 \\
\hline & Resolve aíß & -1.00 & 0.09 & -1.18 & -0.83 \\
\hline & Way táxi® & -1.01 & 0.09 & -1.19 & -0.83 \\
\hline
\end{tabular}




\begin{tabular}{llcccc} 
& Wappa ${ }^{\circledR}$ & -1.03 & 0.09 & -1.21 & -0.85 \\
\hline \multirow{2}{*}{ Videogame } & Play Station ${ }^{\circledR}$ & 0.37 & 0.06 & 0.26 & 0.48 \\
console & X-box ${ }^{\circledR}$ & -0.05 & 0.06 & -0.17 & 0.06 \\
& Nintendo® & -0.31 & 0.06 & -0.43 & -0.20 \\
\hline
\end{tabular}

Source: Prepared by the authors.

Graph A (Figure 2) shows the Estimated Marginal Means of CBBE index in order of magnitude. Values equal to zero mean that the brand is equal to the CBBE index average for all brands. A value equal to one positive (negative) is in a standard deviation above (below) the average. The brands of Uber ${ }^{\circledR}(\mathrm{M}=2.66 ;$ S.E. $=0.1)$ and Visa ${ }^{\circledR}(\mathrm{M}=1.80$;
S.E. = 0.1) presented the highest scores. The Sorocred $\AA(M=-1.18 ;$ S.E. $=0.1)$ brand presented the lowest score. In all, five brands surpassed the limit of one positive standard deviation in relation to the average and three brands surpassed the limit of one standard negative deviation in relation to the average.

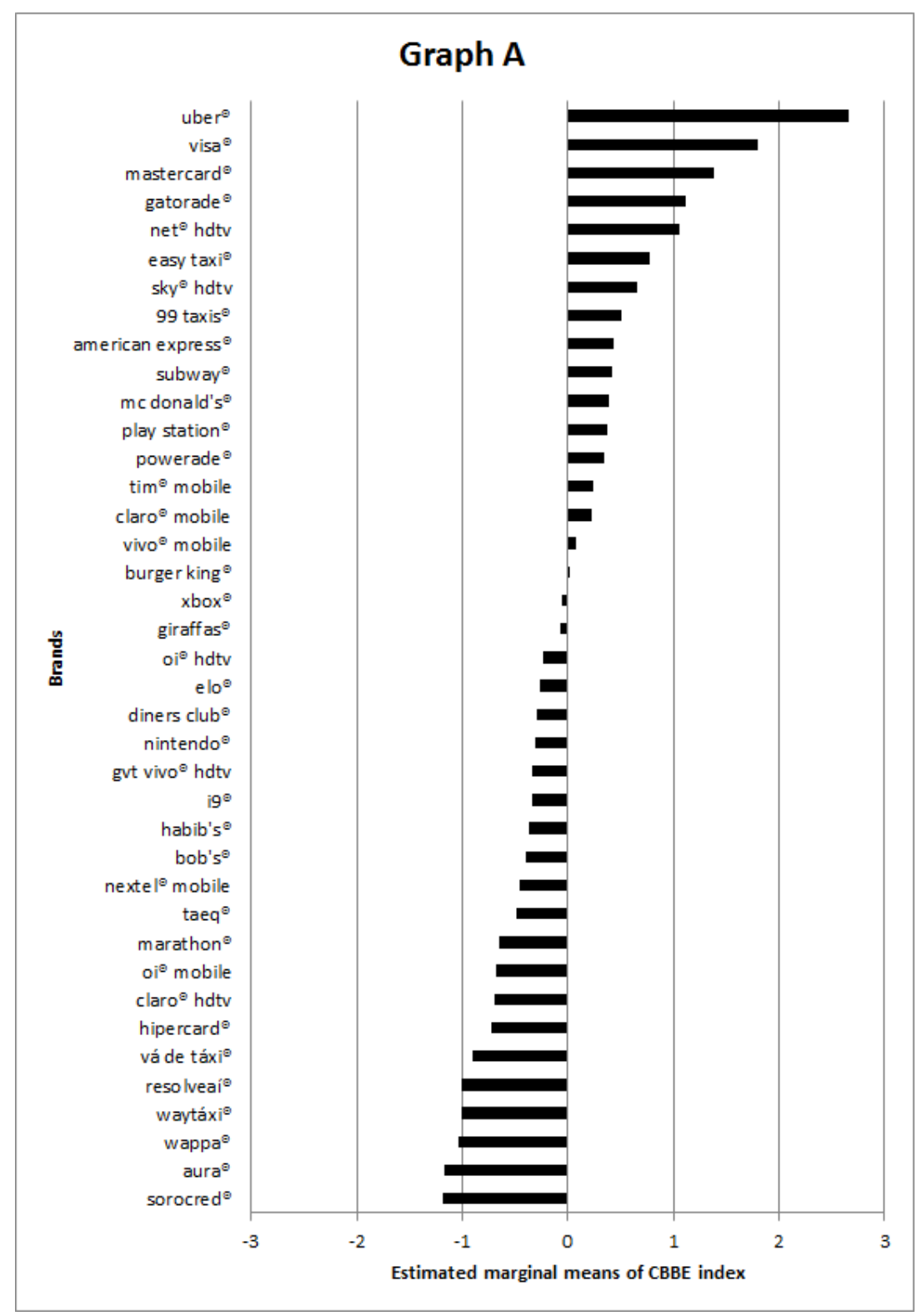

Figure 2 - Ranking when considering all brands of products and services Source: Prepared by the authors. 


\section{DISCUSSION}

Studies concerning CBBE have giving answers to consumer level of analysis, rarely considering the level of brand performance (Tolba \& Hassan, 2009; Wang \& Finn, 2012). This study aimed to overcome some limitations of previously studies, showing a CBBE measurement model capable of considering many substitutable brands (Davcik, Vinhas da Silva, \& Hair, 2015) and consumers' evaluative responses, but taking them to the brand level of analysis. The result may be due to some of the characteristics used in this research, including: (1) the simultaneous use of various competing brands, whether large or small, (2) the aggregation of the consumers' responses to brand metrics, (3) evaluating product brands and services simultaneously, (4) using different scales for the CBBE metrics, and (5) standardize variables prior to their analysis.

The measurement model validated here is seen as an alternative to evaluate CBBE in brand substitutability situations (Foxall et al., 2010; Uncles et al., 2012). The instrument used in this research is able to identify CBBE construct, but with different and complementary metrics, without having to resort to repetitive items to obtain possible dimensions of a multifactorial structure (Clark \& Watson, 1995).

The corroboration of all the hypotheses show that the $\mathrm{CBBE}$ of products and services contains metrics in order of importance: Perceived quality, Awareness, Loyalty, Exclusiveness, Willingness to pay a price premium and Association. These findings corroborate the concepts already obtained by Aaker (1996), Yoo \& Donthu (2001), Netemeyer et al. (2004), but in this study, the author used more direct scales to measure the metrics and take into account the competitiveness that exists between brands, aggregating the consumers' responses.

This research used a response scale capable of supporting measurements in one single study of several brand products and services. Oliveira-Castro et al. (2008) have already done this, although they only included the Awareness and Perceived quality metrics. Notwithstanding, they did not use a confirmatory validation process of the construct, as this study has done. These two metrics, jointly, appear to be the ones that have been investigated the most and are considered to be the most important ones to be measured, which already provide an overall view of $\mathrm{CBBE}$.

In turn, the 'behavioral' Loyalty metric is based on the average purchase frequency for each brand and was inspired by the work of Ehrenberg et al. (2004). Even though based on a self-report, this contributes significantly towards a CBBE construct without redundancy. Loyalty metrics, in the context of CBBE research, are usually based on its 'attitudinal' aspects, which might have artificially correlated with other CBBE concepts derived from perceptions and thereby hindered their discrimination in multifactorial structures (Christodoulides et al., 2015).

The Exclusiveness metric is shown to be good enough to be included within a CBBE construct. The contribution it makes towards CBBE is probably greater for categories that include luxury brands (Hudders, Pandelaere, \& Vyncke, 2013). This research includes only one product/service that is considered to have a luxury brand name, and that is Uber (Black), which is in a category of land transport. This brand obtained the highest score in this survey. Evaluating the level of exclusiveness of a brand can involve issues such as innovation, trademark registration, product patents, monopoly, offering versions of the brand with extra benefits and a scarce supply control of the brand (Oliveira-Castro et al., 2008; Wilke \& Zaichkowsky, 1999). If the category includes brands with substantial differences, this metric is very good at differentiating a luxury brand from all the others.

The Willingness to pay a price premium and Association metrics (positive versus negative valence) are highlighted, because both possess an open-ended response scale and contribute towards the CBBE construct. The Willingness to pay a price premium metric (Netemeyer et al., 2004) makes it possible to know the instant a response is given as to how willing a consumer would really be to pay (the maximum limit) for each one of the brands within a category. On the other hand, the Association metric (Keller, 1993) offers an image measurement in the consumer's own words about each one of the brands belonging to a certain category.

By using an open-ended response scale for Association and Willingness to pay a price premium (Schwarz \& Hippler, 2011), this research introduces a pragmatic approach to management: to understand what terms can be used for positioning and pricing in comparison with other rival brands. Up until now, trying to find CBBE metrics has been the 'Holy Grail' of marketing academia for revealing what consumer-derived information really matters when dealing with brand management (Aaker, 1996).

However, the contribution made by academic research into $\mathrm{CBBE}$ for the purpose of executive decision-making has been very timid, even though the need for this information is desired (Roberts, Kayande, \& Stremersch, 2014) and obvious (Huang \& Sarigöllü, 2012). This is possibly due to the fact that, from a CBBE methodology viewpoint, metrics are not used in a format that helps decision making. The present study shows a useful alternative for brand positioning activities that are reconcilable with other CBBE metrics. 
The Product/Service moderation test showed that the results obtained from them are also very similar. That is to say, in each category, it is important to evaluate the six different metrics in each category, in order to obtain a more complete overview of the CBBE. It does not appear to be more difficult to describe CBBE concepts for services as opposed to products (Christodoulides et al., 2015), but rather that this is a consequence of using measurement instruments that contain items that are very similar to one another - artificially correlations (Clark \& Watson, 1995). For further generalization, this study was concerned with having a sampling of products and services that are purchased on a routine basis, or even purchased sparingly. As a result, it may be safer to measure these to obtain a global evaluation of the brands.

The experience moderation test showed that brand evaluations are very different when made between people who are directly involved in the purchase of a product or service versus those who are not. Taking advantage of information asymmetry (Erdem \& Swait, 1998; Erdem et al., 1999), consumers who have had experience with products or services are better prepared to choose between the alternatives on the closed response scales or to give a better assessment on the open-ended response scales for each brand. Thus, it is recommended that consumers that have brand experience are identified and then consider only experienced consumers in the evaluation process (for the purpose of audit or ranking work), or to consider both (for the purpose of predicting consumer choices).

The index of CBBE makes it possible to compare every brand against one another and to highlight the best and the worst within this criterion, so this indicator becomes as useful as the metricbased indicators that are used by consulting firms (Chu \& Keh, 2006). The best brands (Huang \& Sarigöllü, 2012) are probably those that have done a better job of branding and also by word of mouth. Those placed last have probably not done a good job or did not have the means to do so. This shows that there should be a good relationship (linear and nonlinear) between the CBBE index and business performance (Erdem \& Swait, 2014), especially in a financial dimension, where marketing activities have had significant explanatory power in some financial metrics (Fischer \& Himme, 2016).

\section{FINAL CONSIDERATIONS}

This study revealed the confirmatory factorial validation of a CBBE measurement model for products and services, considering competing brands in the brand level of analysis. Furthermore, it provided evidence of the moderation of consumer experience, as well as the non-moderation of products/services and has constructed a ranking based on the CBBE index. This study thus provides a measurement model capable of evaluating brand performance based on consumer perception. The model encompasses the metrics most commonly used in CBBE surveys by reallocating them to the brand level of analysis, allowing assessing how much one brand achieves greater equity than another of the same category.

Brand researchers and managers can use the instrument described here to evaluate the metrics that really matter for the identification of consumer's perception of brand performance. It is suggested that only the responses from consumers who have product experience be retained and, when establishing a ranking with $\mathrm{CBBE}$ index, all six metrics need to be statistically valid within a $\mathrm{CBBE}$ construct. However, it should be noted that the more product/service categories that the research involves, the bigger the measurement instrument have to be and, as a result, this may become a somewhat tiring experience for the respondents.

One of the possible difficulties involved in using this instrument is the codification of the Association variable. It is possible that the codification in another scale might show a different content. This research used a valence response format (ranging from very negative to very positive). It may be that codifying to what extent a consumer does not recall any word or image related to the brand would be equally relevant.

The metrics used to evaluate products and services refer to brands. However, it should be said that the instrument is not adequate to measure institutions, regions or countries or even personalities (fame). Institutions are not bought by consumers (but are by businessmen, shareholders or investors), which shows that other criteria can be taken into consideration; countries are not bought, but are usually places where people travel or move; personalities are not bought either, but at the most, are paid for their work.

Future researches can be directed towards including a greater diversity of products and services, including more categories that represent luxury brands. In addition, moderation tests should be conducted by using methodological variables, such as, the use of online versus off-line questionnaires or investigate many versus fewer categories of products, which can reveal better/worse contexts for using this measurement model. Trans-cultural research studies are also welcome in order to ensure that this instrument can have greater validity in other cultures and thereby enable comparison of different brands to be made on a global level. 


\section{REFERENCES}

Aaker, D.A. (1996). Measuring brand equity across products and markets. California Management Review, 38(3), 102-120. Doi: 10.2307/41165845

Christodoulides, G. (2015). Brand equity. In C. L. Cooper (Ed.), Wiley Encyclopedia of Management (Vol.9, pp.1-2). Oxfordshire, UK: Wiley. Doi: 10.1002/9781118785317.weom090279

Christodoulides, G., Cadogan, J.W., \& Veloutsou, C. (2015). Consumer-based brand equity measurement: Lessons learned from an international study. International Marketing Review, 32(3/4), 307-328. Doi: 10.1108/IMR-102013-0242

Christodoulides, G., \& De Chernatony, L. (2010). Consumer-based brand equity conceptualization and measurement: A literature review. International Journal of Research in Marketing, 52(1), 43-66. Doi: $\underline{10.2501 / S 1470785310201053}$

Chu, S., \& Keh, H.T. (2006). Brand value creation: Analysis of the interbrand business week brand value rankings. Marketing Letters, 17(4), 323-331. Doi: 10.1007/s11002-006-9407-6

Clark, L.A., \& Watson, D. (1995). Constructing validity: Basic issues in objective scale development. Psychological Assessment, 7(3), 309319. Doi: $\underline{10.1037 / 1040-3590.7 .3 .309}$

Davcik, N.S., Vinhas da Silva, R., \& Hair, J.F. (2015). Towards a unified theory of brand equity: Conceptualizations, taxonomy and avenues for future research. Journal of Product and Brand Management, 24(1), 3-17. Doi: 10.1108/JPBM-062014-0639

Ehrenberg, A.S., Uncles, M.D., \& Goodhardt, G.J. (2004). Understanding brand performance measures: Using Dirichlet benchmarks. Journal of Business Research, 57(12), 1307-1325. Doi: 10.1016/j.jbusres.2002.11.001

Erdem, T., \& Swait, J. (1998). Brand equity as a signaling phenomenon. Journal of Consumer Psychology, 7(2), 131-157. Doi: $\underline{10.1207 / \mathrm{s} 15327663 \mathrm{jcp} 0702 \quad 02}$

Erdem, T., \& Swait, J. (2014). Branding and brand equity models. In R.S. Winer \& S.A. Neslin, (Eds.), The History of Marketing Science (Vol. 17, pp. 237-260). Hanover, USA: World Scientific.
Erdem, T., Swait, J., Broniarczyk, S., Chakravarti, D., Kapferer, J.N., Keane, M.J., Roberts, J., Steenkamp, J.B., \& Zettelmeyer, F. (1999). Brand equity, consumer learning and choice. Marketing Letters, 10(3), 301-318. Doi: 10.1023/A:1008135224357

Farquhar, P.H. (1989). Managing brand equity. Marketing Research, 1(3), 24-33.

Fischer, M., \& Himme, A. (2016). The financial brand value chain: How brand investments contribute to the financial health of firms. International Journal of Research in Marketing, 34(1), 137-153. Doi: $\underline{10.1016 / \text { j.ijresmar.2016.05.004 }}$

Foxall, G.R. (1999). The marketing firm. Journal of Economic Psychology, 20(2), 207-234. Doi: $\underline{10.1016 / \mathrm{S} 0167-4870(99) 00005-7}$

Foxall, G.R. (2015). Operant behavioral economics. Managerial and Decision Economics, 37(4/5), 215-223. Doi: 10.1002/mde. 2712

Foxall, G.R., Wells, V.K., Chang, S.W., \& Oliveira-Castro, J.M. (2010). Substitutability and independence: Matching analyses of brands and products. Journal of Organizational Behavior Management, 30(2), 145-160. Doi: $\underline{10.1080 / 01608061003756414}$

Hair, J.F., Black, W.C., Babin, B.J., \& Anderson, R.E. (2013). Multivariate data analysis New York, NY: Pearson New International Edition.

Huang, R., \& Sarigöllü, E. (2012). How brand awareness relates to market outcome, brand equity, and the marketing mix. Journal of Business Research, 65(1), 92-99. Doi: 10.1007/978-1-49390277-4_8

Hudders, L., Pandelaere, M., \& Vyncke, P. (2013). Consumer meaning making. International Journal of Market Research, 55(3), 391-412.

Doi: 10.2501/IJMR-2013-036

Hunt, S.D. (2010). Marketing theory: Foundations, controversy, strategy, resource-advantage theory. London, England: M E Sharpe.

Jara, M., \& Cliquet, G. (2012). Retail brand equity: Conceptualization and measurement. Journal of Retailing and Consumer Services, 19(1), 140-149. Doi: 10.1016/j.jretconser.2011.11.003

Keller, K.L. (1993). Conceptualizing, measuring, and managing customer-based brand equity. 
Journal of Marketing, 57(1), 1-22. Doi: $10.2307 / 1252054$

Keller, K.L. (2003). Brand synthesis: The multidimensionality of brand knowledge. Journal of Consumer Research, 29(4), 595-600. Doi: $10.1086 / 346254$

Lassar, W., Mittal, B., \& Sharma, A. (1995). Measuring customer-based brand equity. Journal of Consumer Marketing, 12(4), 11-19. Doi: 10.1108/07363769510095270

Lehmann, D.R., Keller, K.L., \& Farley, J.U. (2008). The structure of survey-based brand metrics. International Marketing Review, 16(4), 29-56 Doi: $\underline{10.1509 / \text { jimk.16.4.29 }}$

Marcoulides, G.A., \& Schumacker, R.E. (2013). Advanced structural equation modeling: Issues and techniques. New York, NY: Psychology Press.

Netemeyer, R.G., Krishnan, B., Pullig, C., Wang, G., Yagci, M., Dean, D., Ricks, J., \& Wirth, F. (2004). Developing and validating measures of facets of customer-based brand equity. Journal of Business Research, 57(2), 209-224. Doi: 10.1016/S0148-2963(01)00303-4

Noble, G., \& Basil, D. (2011). Competition and positioning. In G. Hastings, K. Angus, \& C. Bryant, (Eds.), The Sage Handbook of Social Marketing (pp.139-140). London: Sage Publications. Doi: $\underline{10.4135 / 9781446201008}$

Oliveira-Castro, J.M., Foxall, G.R., James, V.K., Pohl, R.H., Dias, M.B., \& Chang, S.W. (2008). Consumer-based brand equity and brand performance. The Service Industries Journal, 28(4), 445-461. Doi: 10.1080/02642060801917554

Oliveira-Castro, J.M., Foxall, G.R., \& Wells, V.K. (2010). Consumer brand choice: Money allocation as a function of brand reinforcing attributes. Journal of Organizational Behavior Management, 30(2), 161-175. Doi: $\underline{10.1080 / 01608061003756455}$

Oliveira-Castro, J.M., Foxall, G.R., Yan, J., \& Wells, V.K. (2011). A behavioral-economic analysis of the essential value of brands. Behavioural Processes, 87(1), 106-114. Doi: 10.1016/j.beproc.2011.01.007

Porto, R.B., \& Oliveira-Castro, J.M. (2015). Consumer purchase and brand performance. In $\mathrm{G}$. Foxall (Ed.), The Routledge Companion to Consumer Behavior Analysis (pp. 175-201). New York, NY: Routtledge.
Roberts, J.H., Kayande, U., \& Stremersch, S. (2014). From academic research to marketing practice: Exploring the marketing science value chain. International Journal of Research in Marketing, 31(2), 127-140. Doi: $\underline{10.1016 / \text { j.ijresmar.2013.07.006 }}$

Samson, A., \& Voyer, B. G. (2014). Emergency purchasing situations: Implications for consumer decision-making. Journal of Economic Psychology, 44, 21-33. Doi: 10.1016/j.joep.2014.05.004

Schwarz, N., \& Hippler, H. (2011). Response alternatives: The impact of their choice and presentation order. In P.P. Biemer, R.M. Groves, L.E. Lyberg, N.A. Mathiowetz, \& S. Sudman (Eds.), Measurement Errors in Surveys (Vol. 173, pp. 41-56). Hoboken, NJ: John Wiley and Sons.

Smith, A. (1784). An inquiry into the nature and causes of the wealth of nations: In three volumes (Vol. 3). London, England: Strahan.

Srinivasan, S., Hsu, L., \& Fournier, S. (2011). Branding and firm value. In S. Ganesan (Ed.), Handbook of Marketing and Finance (pp.155-203). Cheltenham, UK: Edward Elgar Publishing.

Tolba, A. H., \& Hassan, S. S. (2009). Linking customer-based brand equity with brand market performance: a managerial approach. Journal of Product \& Brand Management, 18(5), 356-366. Doi: $10.1108 / 10610420910981837$

Uncles, M., Kennedy, R., Nenycz-Thiel, M., Singh, J., \& Kwok, S. (2012). In 25 years, across 50 categories, user profiles for directly competing brands seldom differ. Journal of Advertising Research, 52(2), 252-261. Doi: 10.2501/JAR-52-2252-261

Wang, L., \& Finn, A. (2012). Measuring consumerbased brand equity across brand portfolios: Manyfacet item response theory perspective. Journal of Targeting, Measurement and Analysis for Marketing, 20(3), 254-260. Doi: $10.1057 /$ jt.2012.20

Wilke, R., \& Zaichkowsky, J.L. (1999). Brand imitation and its effects on innovation, competition, and brand equity. Business Horizons, 42(6), 9-18.

Doi: 10.1016/S0007-6813(99)80033-0

Yoo, B., \& Donthu, N. (2001). Developing and validating multidimensional consumer-based brand equity scale. Journal of Business 
Research, 52(1), 1-14. Doi: $\underline{10.1016 / \mathrm{S} 0148-}$ $\underline{2963(99) 00098-3}$ 